\title{
表面・界面解析のためのX 線回折
}

\author{
X-Ray Diffraction for Surface and Interface Analyses
}

\section{1.はじめに}

纎維・フィルムが外界と接する表面は接着性、撥水・撥 油性、染色性、防污性、静電性、生体適合性、摩擦・摩耗 特性などと密接な関係にある。したがって、これらの関連 する分野では表面を如何に理解し、制御するかが重要とな る。表面の解析には従来からさまざまな手法か提唱されて きた。弚の中で、表面とX線とのかかわりに関しては、X 線光電子分光(XPS)がまず第一に挙げられ文、最近ではX 線反射率2)、表面 NEXAFS 測定が精力的に行われている。 一方、繊維・フィルムが他の物質と接するところには界面 が生じるが、非破壞で界面を解析する手法は現在でも限ら れている。ここでは、表面、さらには界面を解析するため の「X線回折」に関して、われわれの最近進めている研究 を中心にして述べてみたい。

X 線の回折現象はBragg, Laue によって理論力確立され (1912年)、光のわずか 1 年後には、竹・麻など天然繊維 からの回折が世界に先駆けて本邦から報告されだ。また 高分子がまさに原子が共有結合で多数連結された分子であ ることの証明にあたって、X 線回折は歴史上中心的な役割 を果した4)。X線を材料に照射すると、材料による吸収・ 材料からの散乱が生じ、弚の程度は原子番号に比例する。

一般の高分子は炭素、水素をはじめとする軽元素から構成 されていることから、入射 X 線はほとんど吸収されるこ となくバルクにまで達し、回折線には深さ方向に平均化さ れた情報が含まれる。したがって、X 線回折法はむしろ表 面構造に煩わされないことを特長とする、バルクの有力な 構造解析の手段と考えられてきだ”。このようなバルクの 解析法を高分子表面に適用するためには、いくつかの工夫 が必要となる。光れでも X線回折によって他法では得ら れない、表面・界面の構造に関する詳細な知見が得られる ことの意義は大きいと考えている。ここでは i)視斜角入射

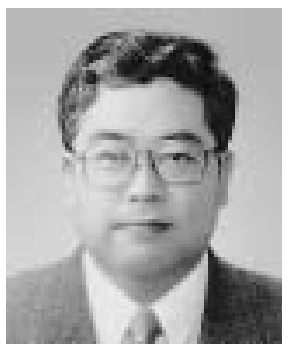

TAKASHI NISHINO

神戶大学 工学部 応用化学科

教授 工博

于 657-8501 神戶市灘区六甲台町 1-1

Tel : 078-803-6164 Fax : 078-803-6198

E-mail : tnishino@kobe-u.ac.jp

〈専門〉高分子固体物性・高分子構造

〈趣味〉読書・詩吟
X 線回折法、ii)放射光を用いたマイクロビーム X 線回折 法を取り上げ、具体例と共に紹介する。

2 . 視斜角入射 $X$ 線回折法

図 1 には、a)広角 $X$ 線回折、b)視斜角入射 X 線回折の

a) 広角X综回折 $(\theta-2 \theta$ 反时法 $)$

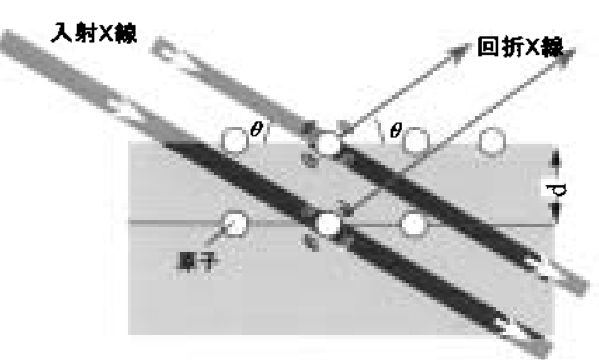

b) 視料角入射X缐回折

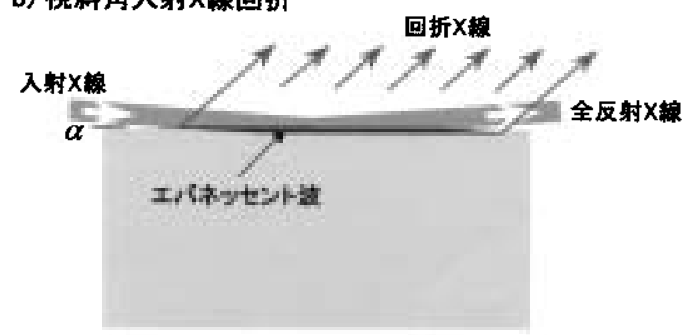

図 1 a)広角 X 線回折、b)視斜角入射 X 線回折の光学系

光学系を模式的に示した。a)では、入射された X 線によっ て原子から新たにX 線が弾性散乱され、散乱波が互いに 干渉した際、Bragg の条件を満足する特定の方向で強め合 い、回折として観察される樣相を示した。この節に、前述 のように入射 $X$ 線はバルク奥深くまで侵入する。一方、X 線の入射角度 $\alpha$ を小さくして表面すれすれに入射すると、 吸収が少ないとはいえX 線は材料に吸収されて徐々に減 衰することから、回折を表面近傍に限定することができる。 すなわち、入射角度を微小にし、X 線の物質内部への侵入 深さを制御することで、表面近傍層の情報が得られる。こ の手法を微小角入射 $X$ 線回折という。さらにb)で示した ように、入射角をより小さくすると、ある臨界角 $\alpha \mathrm{c}$ 以下 ではX 線はついには表面で全反射するようになる。この 際、回折に与るX 線は試料表面にわずかに染み込むエバ ネッセント波のみに由来する。この場合の X 線回折を微 小角入射 $X$ 線回折の中でも特に、視斜角入射 $X$ 線回折 (Grazing Incidence X-ray Diffraction ; GIXD)という。 
図 2 には、アイソタクチック・ポリプロピレン (it.PP) に対して、入射角度 $\alpha$ とX線の侵入深さの関係を示した。

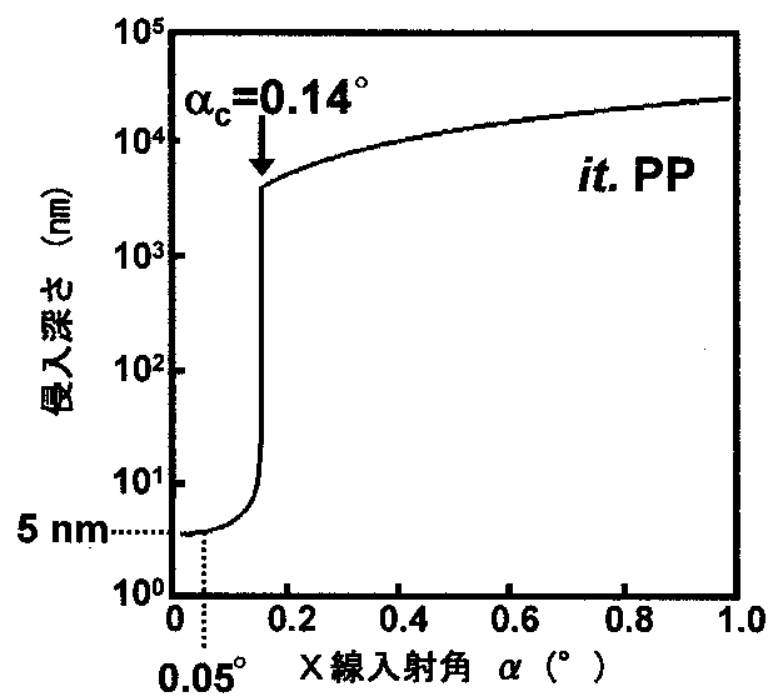

図 $2 \mathrm{X}$ 線入射角 $\alpha$ とアイソタクチック・ポリプロピレン に対する侵入深さの関係

ここでは侵入深さを、X 線の強度が1/e になるまでの表面 からの深さと定義している。CuK $\alpha$ 線に対して it. PP の臨 界角 $\alpha \mathrm{c}$ は $0.14{ }^{\circ}$ となり、この角度を挟んで侵入深さが大

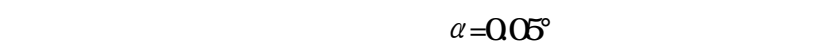
面から約 $5 \mathrm{~nm}$ までの深さの情報が得られることになる。 この侵入深さはXPSの検出深さにほぼ対応する。一方、 入射角が $\alpha c$ を越えるとX 線の侵入深さは急激に大きくな り、材料による吸収で規定されるようになる結果、 $\alpha=0.2^{\circ}$ では約 $10 \mu \mathrm{m}$ 侵入する。このことから、 $\alpha$ の值を変化させ てX線回折を行えば、XPSレベルから FTIR ATRレベル ひいてはバルクまで、表面から深さ方向への構造解析が可 能になる。

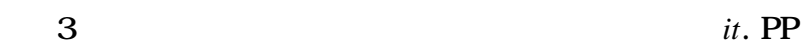
フィルムのX線回折プロファイルをバルクと表面 $(\alpha=$ $\left.0.05^{\circ}\right)$ につて示した。なお、溶融状態から急冷した後、 フィルムには $100^{\circ} \mathrm{C} て ゙ 10$ 分間の熱処理を施した。it. PP にはさまざまな結晶多形の存在が知られているが、各々図

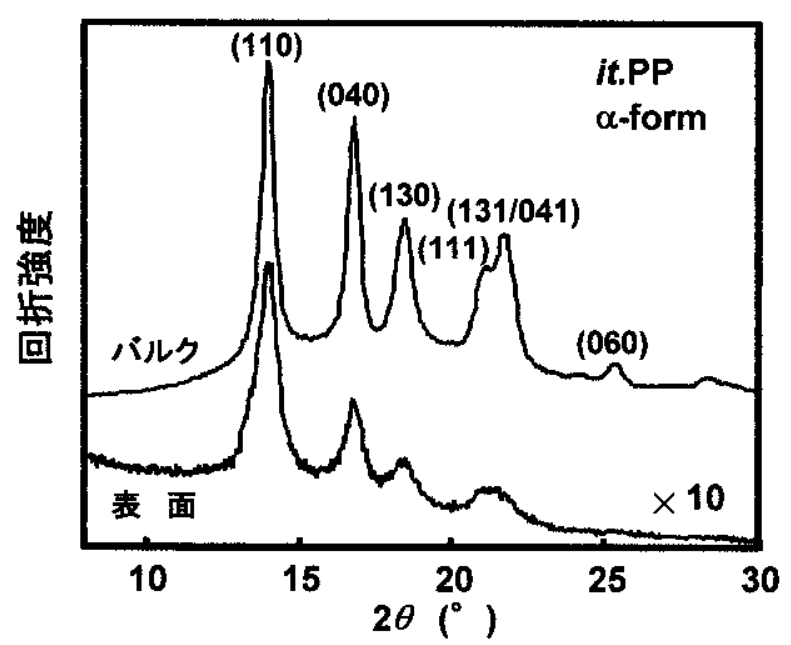

図 3 アイソタクチック・ポリプロピレンのバルクと表面 のX線回折プロファイル
中に示したように、この試料は $\alpha$ 型結晶で指数付けする ことができた。プロファイル全体について観ると、バルク に比較して表面の方か散漫である。このことは、表面の結 晶化度が低いことを意味している。光こで、便宜上 Weidinger,Hermans らの方法7)適用することによりX 線

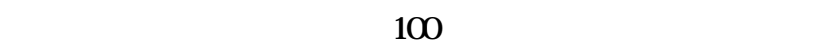
度の変化を図 4 に示した。熱処理時間に伴い、バルク・表

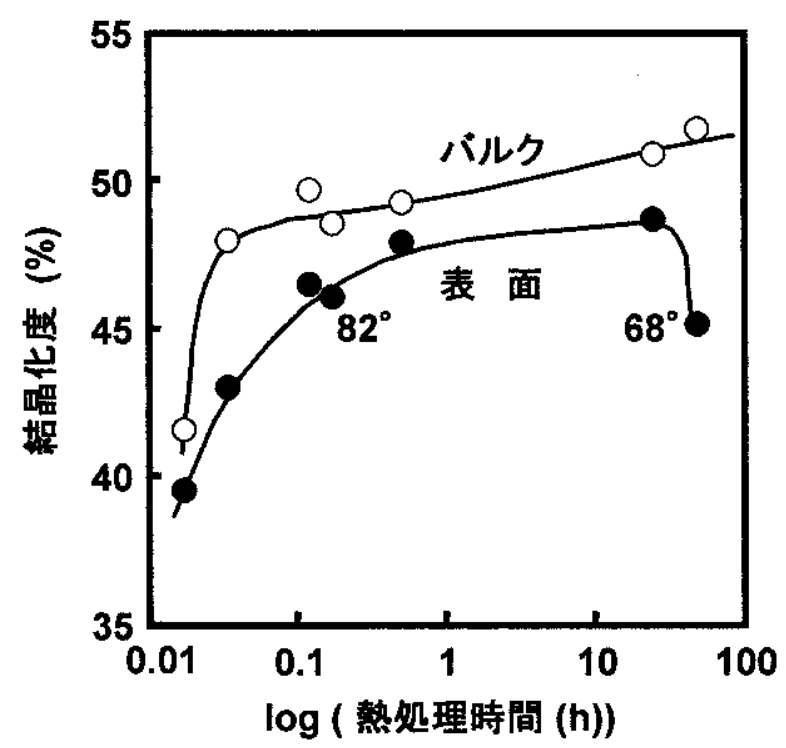

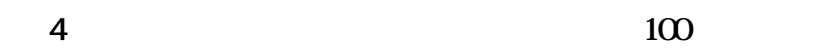
処理時間と結晶化度の関係

面ともに結晶化度は上昇し、表面の結晶化度はいったんバ ルクの值に漸近するが、いずれの場合もバルクに比較して、 表面の結晶化度は低かった。さらに熱処理時間を長くする とバルクの結晶化度は上昇するものの、表面の光れは低下 してしまう。これは長時間に亘り高温・空気中に暴露した ことでフィルム表面か酸化劣化したことに基づいている。 このことは、図中数字で示した水との接触角の結果と対応 している。このように、視斜角入射 $x$ 線回折において構 造パラメーターとして結晶化度を追跡することで、表面の 状態分析も可能となる。

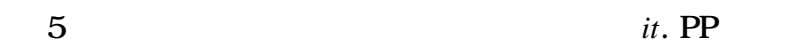
ルムの(110)面の面間隔と $X$ 線の入射角度 $\alpha$ の関係を示し た。 $100^{\circ} \mathrm{C}, 10$ 分間の熱処理ではバルクに比較して、表面 の面間隔が小さく得られた(図中○)。これは溶融状態から の急冷の際に外側から冷やされることで、フィルム表面に 圧縮のひずみが残留し、この程度の熱処理では除去されて いないことを意味している。結晶弾性率帛との積から、こ の圧縮残留応力は 8.4MPa と見積もられた。一方、熱処理 時間を 30 分間にすると表面からバルクに亘って面間隔は 一定の値となり、残留応力は緩和された。さらに、熱処理 温度を $150^{\circ} \mathrm{C}$ にすると、10 分間という短時間で残留応力 は緩和され、また、熱処理効果により面間隔の絶対值も小 さくなった。

図 6 には、アイソタクチック・ポリブテン-1(it. PB-1)

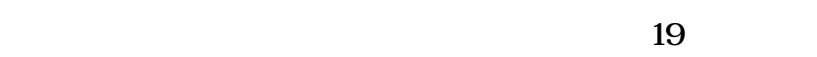
した際の表面 $\left(\alpha=0.05^{\circ}\right)$ およびバルクのX 線回折プロファ 


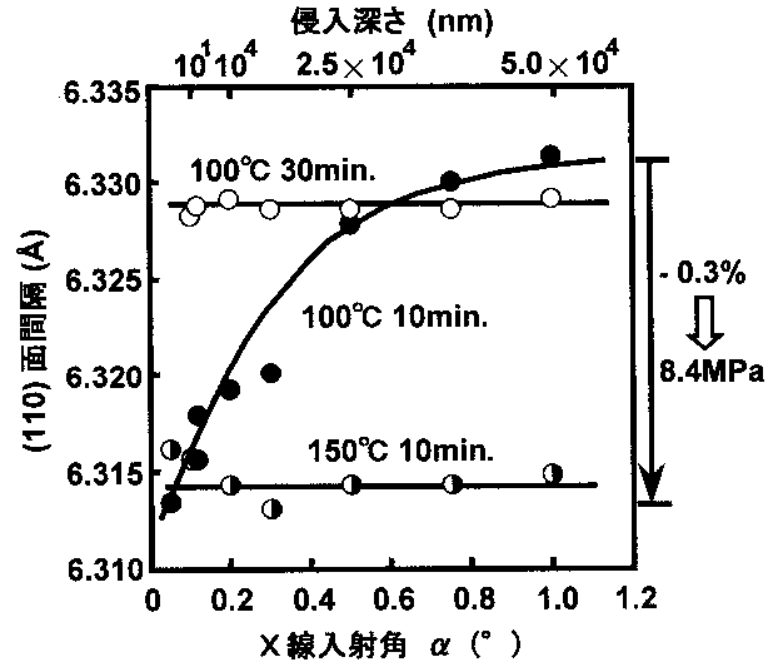

図 5 アイソタクチック・ポリプロピレンの(110)面の面 間隔と X 線入射角の関係
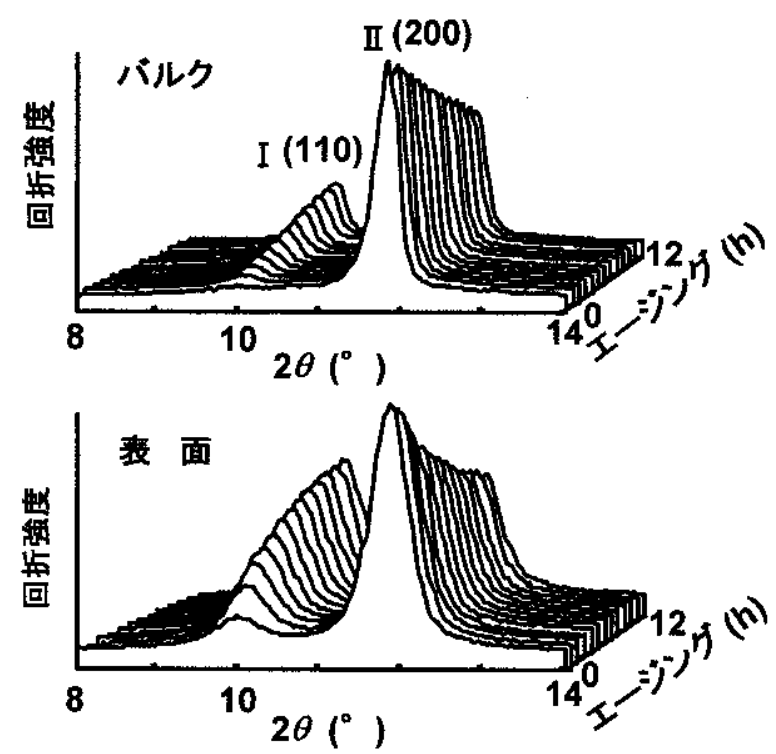

图 6 アイソタクチック・ポリプロピレンのバルクと表面 のX線回折プロファイルの経時変化

イルの経時変化を示した。まず急冷直後についてみると、 バルクに比較して表面では回折ピークの半価幅が広く、結 晶サイズが小さいことがわかる。これは上述の it. PP と同 じポリ- $\alpha$-オレフィンである it. PB-1においても、表面の 結晶化度が低いことに対応している。さて、it. PB-1は溶 融状態からの急冷により、いったん速度論的に優勢な II 型 として結晶化するが、熱力学的に安定な I 型結晶へと室温 においても徐々に転移することが知られている。图の例で もII型 200 反射の強度が低下し、一方、I 型 110 反射の強 度が増加した。この際、表面では急冷直後に既に II 型が出 現し、II 型 $\rightarrow$ I 型への結晶転移はより促進された。近年、

さまざまな解析により高分子表面では分子鎖の運動性の高 いことが明らかにされている9。it. PB-1の結晶転移が表 面で促進される現象もやはり表面分子鎖の高運動性で説明 することができる。

二種類以上の高分子をブレンドした場合、表面組成がバ ルクとは著しく異なる場合がある。多くの場合、表面自由
エネルギーを最小にしようとするドライビングフォースに 基づく現象であり、含フッ素高分子をブレンドした場合に 顕著に生じる ${ }^{10)}$ 。分析にあたってはXPS, FT - IR ATR など が用いられるが、ブレンドする高分子同士の化学構造が類 似していると、表面組成の決定は困難になる。この点、物 理的な構造をモニターするX線回折法では、たとえばポ リ- $\alpha$-オレフィン同士のブレンド物でも両者を明瞭に区別 することができる。

图 7 には、一例として it. PP と it. PB-1のブレンド物の GIXD プロファイル $\left(\alpha=0.05{ }^{\circ}\right)$ を示した ${ }^{11)}$ 。ブレンド比は

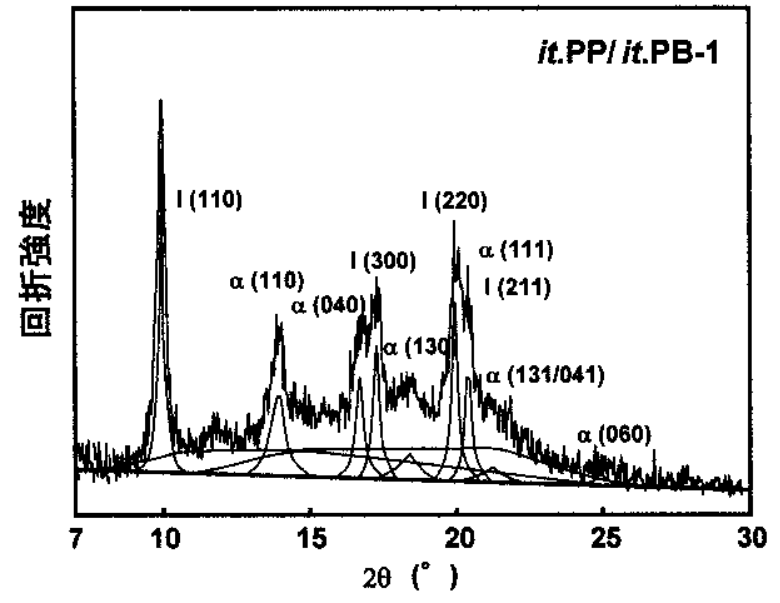

图 7 アイソタクチック・ポリプロピレン/アイソタク チック・ポリプロピレンブレンド物表面のX線回 折プロファイル

50 : 50(重量比)であり、メルトから急冷したのち室温で1 ヶ月放置後のプロファイルを示した。it. PP $\alpha$ 型のピーク と it. PB-1のI型のピークが複雑に混在しているが、図の ように指数付けが可能であり、両者の回折強度比から表面 組成を求めたところ、64:36(重量比)となり、表面で it. PP が優先的に存在することを明らかにした。さらに、この場 合はブレンドすることにより、it. PB-1のI型から। 型へ の結晶転移が表面でより促進されていることも併せて見出 した。

これまでは主にポリー $\alpha$-オレフィン表面の解析事例につ いて述べてきたが、次に界面解析のためのX 線回折につ いて具体例を挙げる。

シリコンウェハ上にアタクチック・ポリビニルアルコー ル $(\mathrm{PVA})$ 水溶液をスピンコート(厚み $60 \mathrm{~nm})$ し、次いでア イソタクチック・ポリスチレン (it. PS)をトルエン溶液か ら重ねてスピンコート(厚み 180nm)することで高分子/ 高分子界面を作製した。ここでPVA の $\alpha \mathrm{C}$ が $0.170^{\circ}$ であ るのに対して、it.PSの $\alpha \mathrm{c}$ は $0.158^{\circ}$ である。つまり、両 者の $\alpha$ の間の角度でX 線を入射すると、it. PS 層を突き抜 けて，it. PS/PVA 界面で全反射が生じ、界面近傍のPVA の構造を捉えることができる。

图8には、it.PSをスピンコートする前のa)PVA 薄膜 全体からのX 線回折プロファイル、c)PVA 薄膜のさらに 表面からのX 線回折プロファイル、および $) i t . P S$ を重ね てスピンコートしたのちの it. PS/PVA 界面のPVA からの 


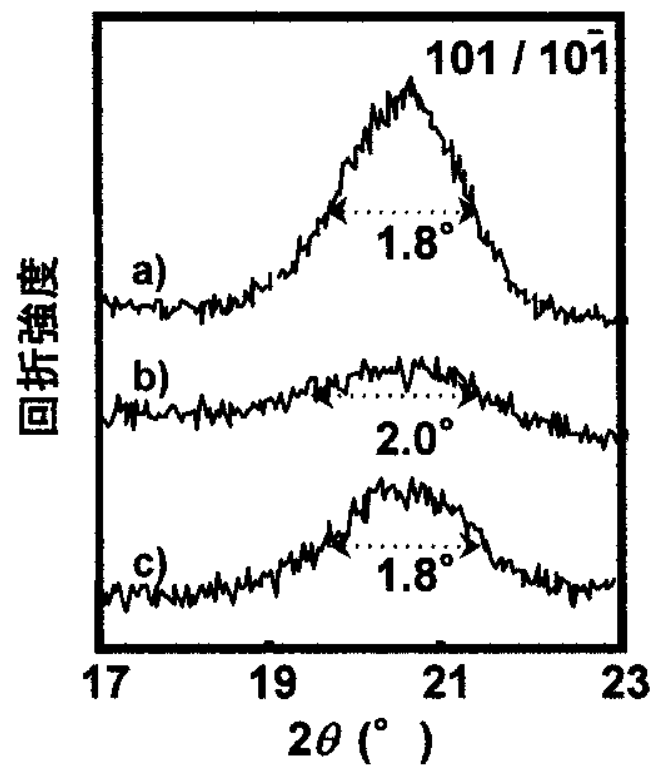

図 8 a)ポリビニルアルコール薄膜全体、b)ポリビニル アルコール薄膜表面、c)ポリビニルアルコール $/ ア$ イソタクチック・ポリスチレン積層薄膜界面の $\mathrm{X}$ 線回折プロファイル

X 線回折プロファイルを示した ${ }^{12)}$ 。なお、いずれの試料に 対しても測定に先立って $200^{\circ} \mathrm{C} て$ 熱処理を施した。薄膜で はX線による被照射体積が元来小さいため、通常の広角 $X$ 線回折の測定を行ってもバックグラウンドが得られるのみ である。兰れに対して入射角度 $\alpha$ を $0.2^{\circ}$ に設定した測定 では、a)で示したように厚さ 60nm のPVA 薄膜の 101/101 反射が明瞭に得られた。このことから、微小角入射 $X$ 線 回折は別名「薄膜 X 線回折」とも呼ばれている。次に、 $\alpha$ を $0.05^{\circ}$ にすると、b)で示したように、PVA 薄膜のさらに 表面からの回折が得られた。この際、見かけの積分幅が表 面では広くなっている。つまり、薄膜においても表面とバ ルクを区別することができ、表面では微結晶サイズが小さ いことを意味している。ところがPVA 薄膜の上に $i t . P S$ 層を重ねて、かつ熱処理を行うと、界面では積分幅が小さ くなり、バルクの値とほぼ等しくなった。このことは、熱 処理を施しても、バルクに比較して表面では微結晶サイズ は小さいが、一方、界面では結晶が成長してサイズが大き くなることを意味している。一般に、二種類の物質の接す るところを「界面」といい、光の中でも特に気体と接する 場合を「表面」と呼称する。表面と界面は並べて論じられ ることが多いが、ここで示したように、接する相手によっ て光れらの構造は大幅に変化する。現在、接触媒体を異に する際の表面、界面構造の解析を進めている。

\section{3. マイクロビームX線回折法}

前項ではX 線回折の際の光学系を調節することで表面・ 界面の解析を行ってきた。場所として表面・界面という以 外は, この解析によって得られる知見は通常のX線回折 の場合と何ら異なることなく、多彩である。ところが、こ の手法の難点をひとつ挙げるとすれば、測定に供する表面・ 界面が平滑である必要がある。兰こで次に、入射する X
線のビームサイズを小さくして、バルクと界面を見分ける 手法について述べる。この手法は原理的に荒れた表面、界 面に対しても適用が可能である。

可視光線は光学レンズを通して集光することができるが、 波長が長いために空間分解能に限界がある。同じ電磁波で あるX線は高い物質透過性を有し、波長が短いため高い 分解能か期待できる。さらに、測定は大気中で可能である 上、特殊な試料調整が不要であり、非破壞的な観察が可能 であるなどのさまざまな利点を有している。ところが、 $x$ 線はレンズで集光することができず、高分解能観察の観点 からは従来、電子という電荷をもった粒子をレンズで集光 して利用する「電子顕微鏡」や「電子線回折」が汎用され てきた。一方、最近ではX線を集光するためのさまざま な手段が開発されている。光の中でもわれわれは、位相ゾー ンプレート (ZP)を用いて硬 X 線を集光して得られるマイ クロビームを利用した X 線回折を試みている ${ }^{13)}$ 。ZP とは $\mathrm{X}$ 線に対して透明・不透明の輪帯か交互に同心円状に繰り 返した円形の透過型回折格子であり、透過したX X 線が試 料位置で焦点を結ぶようにしてある。これにより現在のと ころサブミクロン程度の直径の硬 $X$ 線ビームが得られて いる。この際、試料に入射するX 線は、予めZP を通過し、 しかもマイクロビームであるためフォトン数が極端に減少 する。つまり入射 X線強度が低いため、回折線はさらに 微弱となって検出には困難を伴う。乥のため、ZP を利用 したマイクロビームX 線回折のためには光源として輝度 の高い放射光を利用する必要がある。

図 9 には、it. PP と低密度ポリエチレン(PE)のラミネー 卜界面付近にマイクロビーム $X$ 線を入射した際に得られ た X線回折プロファイルを併せて示した。実験には第三 世代大型放射光施設である SPring-8において、兵庫県立 大学・篭島先生によって構筑されたマイクロビームライン (BL24XU)を利用させていただいた ${ }^{14)}$ 。图よりまず、界面 近傍で $P E$ 側の $a$ 点では $P E$ 由来の回折プロファイルが得 られている。次に a点より $1.56 \mu \mathrm{m}$ だけ it. PP 側に寄った ところでは、PE に加えて it. PP 由来の回折ピークが出現 したはお、用いたX線の波長が異なるため、ピークの現

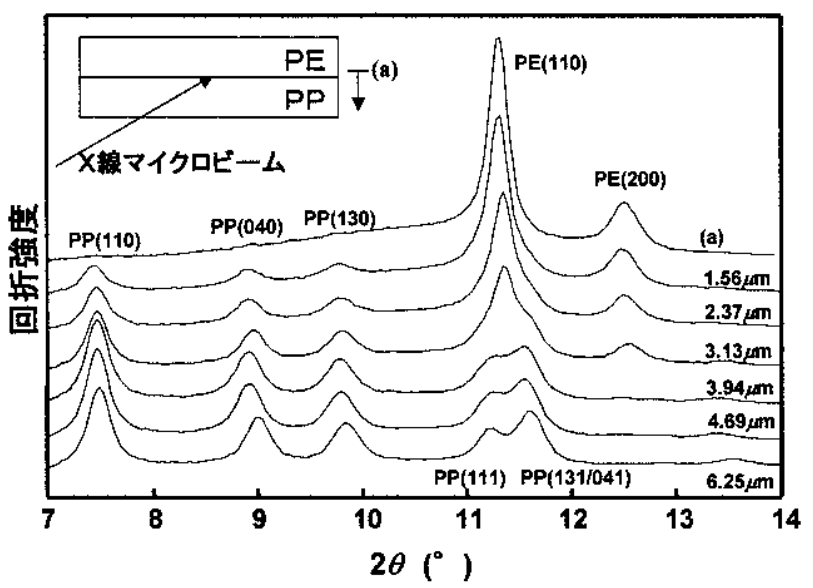

图 9 ポリエチレン/アイソタクチック・ポリプロピレン 積層膜界面近傍のマイクロビーム X 線回折 
れる回折角は図 3 と異なっている)。以降 $a$ 点から離れる につれてPE のピークは弱くなり、一方、it. PP のピーク は強くなり、ついに $6.25 \mu \mathrm{m}$ 離れたところでは it. PP 由来 のピークのみとなった。技術的に解決すべき課題は残って いるが、上の結果はPE/it. PP の界面がミクロンオーダー の厚みを持っていることを示唆している。

マイクロビームを利用したX 線回折はこのような界面 の解析以外にも、既に合成繊維、天然繊維のスキン-コア 構造の解析か試みられている ${ }^{15)}$ 。さらに微小部分の結晶配 向解析やナノファイバーの解析にも今後利用が考えられる。 また、回折現象を利用するだけでなく、マイクロビームを 利用した蛍光 X 線分析、X 線顕微鏡、in situ イメージング 像観察など䋊維・フィルム分野での利用が大いに期待でき る。

\section{4.おわりに}

$X$ 線を表面すれすれに入射する視斜角入射 $X$ 線回折法、 X 線をゾーンプレートで絞るマイクロビーム X 線回折法を 利用して、表面・界面構造に関する知見が得られることを 具体例を挙げて示してきた。紙面の都合上、私どもの研究 紹介が主になった。文献・詳細については最近の拙著をご 覧いただければ幸いである鼻)。前者は 25 年前に Marra ら ${ }^{17)}$ により提唱されたが、高分子系への適用はやっと前世紀末 からである。微小角入射 X 線回折については装置が市販 されるようになり、SPring-8を利用した高分子材料の解 析も盛んになってきた。硬X線マイクロビームについて はまさに研究が緒についた段階で、今後の展開が楽しみで ある。繊維・フィルムに関しても今後益々適用例が増え、 界面・表面の構造解析に関する知見か蓄積されてゆくこと を切に望んでいる。

\section{文献}

1) G. Beamson and D. Briggs, High Resolution XPS of
Organic Polymers, J. Wiley \& Sons, Chichester (1992).

2) 毛利恵美子、松本幸三、松岡秀樹、高分子、53，486 (2004).

3) S.Nishikawa and S.Ono, Proc. Math. Phys. Soc. Tokyo, 7, 131(1913).

4) 野村春治、梶 慶輔、繊維学会誌、53, P-129(1997).

5) M. Kakudo and N. Kasai, X-ray Diffraction by Polymers, Kodansha Sci.(1972) ; 田所宏行、高分子の構造、化学 同人、京都(1976).

6) T. Nishino, T. Matsumoto and K. Nakamae, Polym.Eng. Sci., 40, 336(2000).

7) A. Weidinger and P. H. Hermans, Makromol. Chem., 50, 98(1961).

8) 桜田一郎、伊藤泰輔、中前勝彦、高分子化学，21, 197 (1964).

9) 梶山千里、高原 淳、機能材料，23，5(2003), 田中 敬二．高分子，53, 495(2003).

10) 西野 孝、日本接着学会誌，35, 170(1999).

11) 西野 孝、椋本 将、中前勝彦、Polym. Prepr. Jpn., 50, 2782(2001).

12）西野 孝、中野真人、中前勝彦、Polym. Prepr. Jpn., 48, 3619(1999).

13）小寺 賢、西野 孝、Polym. Prepr. Jpn., 52, 2983(2003).

14) Y. Kagoshima, K. Takai, T. Ibuki, Y. Yokoyama, T. Hashida, K. Yokoyama, S. Takeda, M. Urakawa, N. Miyamoto, Y. Tsusaka and J. Matsui, Nucl. Instrum \& Methods. A 467, 468, 872(2001).

15) M. Müller, C.Riekel, R.Vuong and H.Chanzy, Polymer, 41, 2627(2000).

16) 西野 孝、中前勝彦、表面解析・改質の化学、日本 接着学会編、日刊工業新聞社(2003).

17) W. C. Marra, P. Eisenberger and A. Y. Cho, J. Appl. Phys., 50, 6927(1979).

第 6 回国際絞り会議 2005 JAPAN(略称 ISS - 2005) The 6 th International Shibori Symposium 2005 in J apan -- SHIBORI : 創生と進化 --

主 催 : ワールド絞りネットワーク(WSN) 共 催 : 多摩美術大学 後 援 : 外務省、文化庁、(社繊維学会 ほか 世界の絞りをキーワードに伝統的ワークから最先端技術に至るテキスタイルワークの最前線を提示し、未来を拓く繊 維産業の発展と世界䋊維文化の高揚、発展に寄与する。

会 場・開催日：○本会議＼cjkstart東京/多摩美術大学・八王子キャンパス 平成 17 年 5 月 14 日(土) 17日(火) ○ポスト会議＼cjkstart名古屋・有松／愛知県絞工業組合会館＼cjkstart平成 17 年 5 月 19 日(木) 22日(日)

基調講演 : ホーリー・ホッチャー Holly Hotcher(アート・アンド・デザイン・ミュージアム館長／アメリカ） バシリス・ジディアナキス Vasilis Zidianakis(インデペンデントコスチュームキュレーター/ギリシャ) 皆川魔鬼子 Makiko Minagawa (多摩美術大学教授、(株)イッセイ・ミヤケ取締役/日本)

問い合せ先 : ISS-2005 Symposium TOKYO ７ 158-0094 東京都世田谷区玉川 1-12-13

TEL : 03-3709-0622 FAX:03-3709-0625 E-mail :t-astyle@gol.com http ://www.tamabi.ac.jp/tx/iss/ 